\title{
Population dynamics and genotypic richness of threatened Acropora species and their hybrid in the U.S. Virgin Islands
}

\author{
Hannah F. Nylander-Asplin ${ }^{1,2}$ (1) Ronald L. Hill $^{2} \cdot$ Jennifer C. Doerr $^{2} \cdot$ \\ Lisa Greer ${ }^{4} \cdot$ Nicole D. Fogarty ${ }^{3}$
}

Received: 11 March 2020/Accepted: 3 April 2021/Published online: 22 April 2021

(C) The Author(s) 2021

\begin{abstract}
Acropora cervicornis and A. palmata have experienced substantial losses in coral cover throughout the Caribbean, but their hybrid (A. prolifera) appears to be increasing at some sites. The shifts in relative abundance could result from hybridization with subsequent asexual fragmentation, recent increased hybridization, or a disproportionate loss in the parental species. Here, acroporid taxa from three U.S. Virgin Islands sites were genotyped revealing 35 hybrid genotypes, suggesting multiple hybridization events. Genotypic richness in A. cervicornis (0.62), A. prolifera (0.64), and A. palmata $(0.68)$ was not significantly different across sites. To further explore acroporid dynamics at these sites, we analyzed existing photo transects from 2009 to 2017 to reveal significant losses of A. cervicornis but stable hybrid percent cover. High genotypic richness and stable populations suggest acroporid hybrids may become the primary shallow reef-
\end{abstract}

Topic Editor Carly Kenkel

Supplementary Information The online version contains supplementary material available at https://doi.org/10.1007/s00338021-02093-y.

Hannah F. Nylander-Asplin

hannah.nylander-asplin@noaa.gov

1 Department of Marine and Environmental Science, Nova Southeastern University, Dania Beach, FL, USA

2 NOAA National Marine Fisheries Service, Southeast Fisheries Science Center, Galveston, TX, USA

3 Department of Biology and Marine Biology, Center for Marine Science, University of North Carolina, Wilmington, USA

4 Geology Department, Washington and Lee University, Lexington, VA, USA builders in some locations previously occupied by the parental species.

Keywords Acropora cervicornis - Acropora palmata . Acropora prolifera $\cdot$ Hybridization $\cdot$ Coral reefs

\section{Introduction}

Caribbean acroporid corals have experienced extensive declines due to storm events, coral bleaching, and disease (Hoegh-Guldberg et al. 2007; Hoegh-Guldberg and Bruno 2010). First noted in the 1970s with continued impacts, white band disease has reduced A. cervicornis (staghorn) and A. palmata (elkhorn) coral cover by up to $97 \%$ throughout the Caribbean (Gladfelter 1982; Aronson and Precht 2001; Gignoux-Wolfsohn et al. 2012; Randall and van Woesik 2015). These species are critical for maintaining shallow coral reef ecosystems due to their rapid accretion rates and ability to create complex habitats for ecologically and economically important reef-dwelling species (Gladfelter et al. 1978; Brock et al. 2004).

While A. cervicornis and A. palmata have decreased significantly, the naturally occurring hybrid, A. prolifera, has been reported at equal or higher abundances than the parental species at some Caribbean sites (Fogarty 2012; Japaud et al. 2014; Aguilar-Perera and Hernandez-Landa 2018; Weil et al. 2020). The hybrid has an intermediate morphology (ESM Fig. 1) and although previously reported in marginal habitats, has recently been found to cooccur with one (Fig. 1) or both parental species (Fogarty 2012; Goreau 1959; Gladfelter et al. 1978; Cairns 1982; Wallace 1999; Cortes 2003). The apparent increase in hybrid abundance may be from increased survival and spread of asexually produced fragments from hybridization 


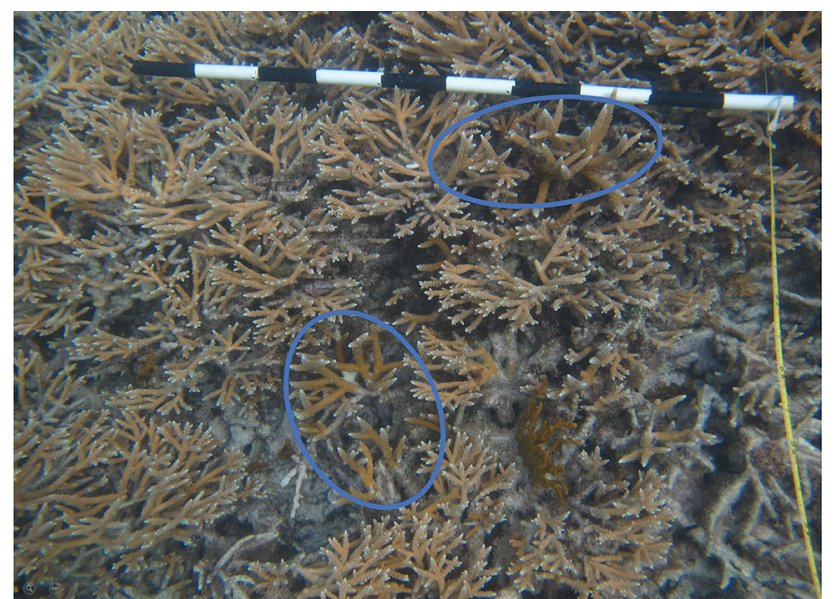

Fig. 1 Acropora cervicornis co-occurring with the hybrid (A. prolifera) at No Name Bay in the U.S. Virgin Islands in April 2012. The hybrid is seen surrounding two A. cervicornis colonies (blue)

events, disproportionate losses of the parental species, or production of hybrid colonies through sexual reproduction between the parental species. Acroporid hybridization can result from asymmetric losses in the parental species, and/ or weak pre-and post-zygotic reproductive isolating barriers allowing for more frequent hybrid embryo formation, and weak selection on hybrid adults (Fogarty 2010; Fogarty et al. 2012). Here, we untangle the mechanism of differential hybrid abundance through genotypic analysis of the three acroporids and utilize a long-term dataset of the benthic cover to quantify the change in percent cover of the hybrid and one of the parental species, A. cervicornis.

\section{Methods}

\section{Permanent transects, percent live coral cover, and tissue condition analysis}

Nine permanent transects $(10 \mathrm{~m} \times 2 \mathrm{~m})$, originally established to monitor changes in A. cervicornis and associated fish assemblages were surveyed at three sites in the northern U.S. Virgin Islands (Fig. 2). Only A. cervicornis was present on the four transects at Thatch Cay $\left(18.35666^{\circ}\right.$ $\left.\mathrm{N}, 64.85628^{\circ} \mathrm{W}\right)$ and the two transects at Lovango Cay $\left(18.36546^{\circ} \mathrm{N}, 64.80249^{\circ} \mathrm{W}\right)$, while A. cervicornis and the hybrid were present on the three transects at No Name Bay $\left(18.34966^{\circ} \mathrm{N}, 64.67109^{\circ} \mathrm{W}\right)$. At each survey between 2009 and 2017, planar photographs were taken every $1 \mathrm{~m}$ along both sides of each transect. Photographs $(n=2880)$ from surveys conducted in March, July, and November 2009, April 2010, April 2012, September 2014, August 2015, July 2016, and August 2017 were used to quantify percent live acroporid cover along each transect. Due to equipment failure, Thatch Cay transects were not surveyed in April 2012 and only 3 of the 4 transects were surveyed in 2014 . Each photo was scaled and rectified using MatLab R2017b (Yang et al. 2009) (Fig. 3). Acroporid colonies were digitized using Adobe Illustrator 2017, with portions categorized as "pigmented" that may be slightly pale in color or "white" from recent death or bleaching. All images were analyzed by a single researcher to reduce subjective visual bias.

\section{Tissue sampling and genotypic analysis}

In 2017, 1-cm tissue samples were collected from the apical tips of A. cervicornis $(n=50)$, A. palmata $(n=40)$, and A. prolifera $(n=39)$ from each of the three sites (Fig. 2). Samples of A. cervicornis and hybrid colonies were collected within permanent transects, as available. Additional colonies of all taxa were selected haphazardly in areas surrounding the transects to standardize sample size and distribution (Fig. 2).

Samples were genotyped using microsatellites developed by Baums et al. (2009) and with protocols modified by Fogarty et al. (2012). Samples were transferred from 96\% ethanol to CHAOS (4 M guanidine thiocyanate $0.1 \%$ N-lauroylsarcosine sodium salt, $23 \mathrm{mM}$ Tris $\mathrm{pH} 8,0.1 \mathrm{M}$ 2-mercaptoethanol, ultra-pure water) for tissue digestion. DNA was extracted using a SprintPrep DNA Purification kit, magnetic bead-based protocol (Beckman Coulter Genomics/Agencourt Bioscience Corporation). DNA was quantified using a microplate spectrophotometer (Nanodrop) and PCR amplified using five microsatellite primers [loci 166, 181, 187, 182, 207 (Baums et al. 2009)]. The PCR products were multiplexed in two combinations (ESM Table 1) and analyzed by the Florida State University Sequencing Facility. Micro-checker 2.3.3 was used to isolate allele dropout, null alleles, and stutter peaks. Stutter peaks occurred at a low frequency $(\rho=0.11)$ in one allele at locus 207. Peak calls were performed in GeneMapper 5 Software. Due to unequal sample sizes among the acroporids collected at each site, genotypic richness (the total number of unique genotypes divided by the total number of samples) was the preferred metric (Stoddart and Taylor 1988; Baums et al. 2006).

\section{Statistical analysis}

Statistical analysis was conducted using R.3.5.1 software. Coral cover, genotypic richness (log transformed), and tissue condition were tested for normality (Shapiro-Wilk test) and homogeneity of variances (Bartlett's test). A $t$ test was used to determine significance in genotypic richness. A multiple linear regression and nested ANOVA were used to identify differences among sites and sampling periods 

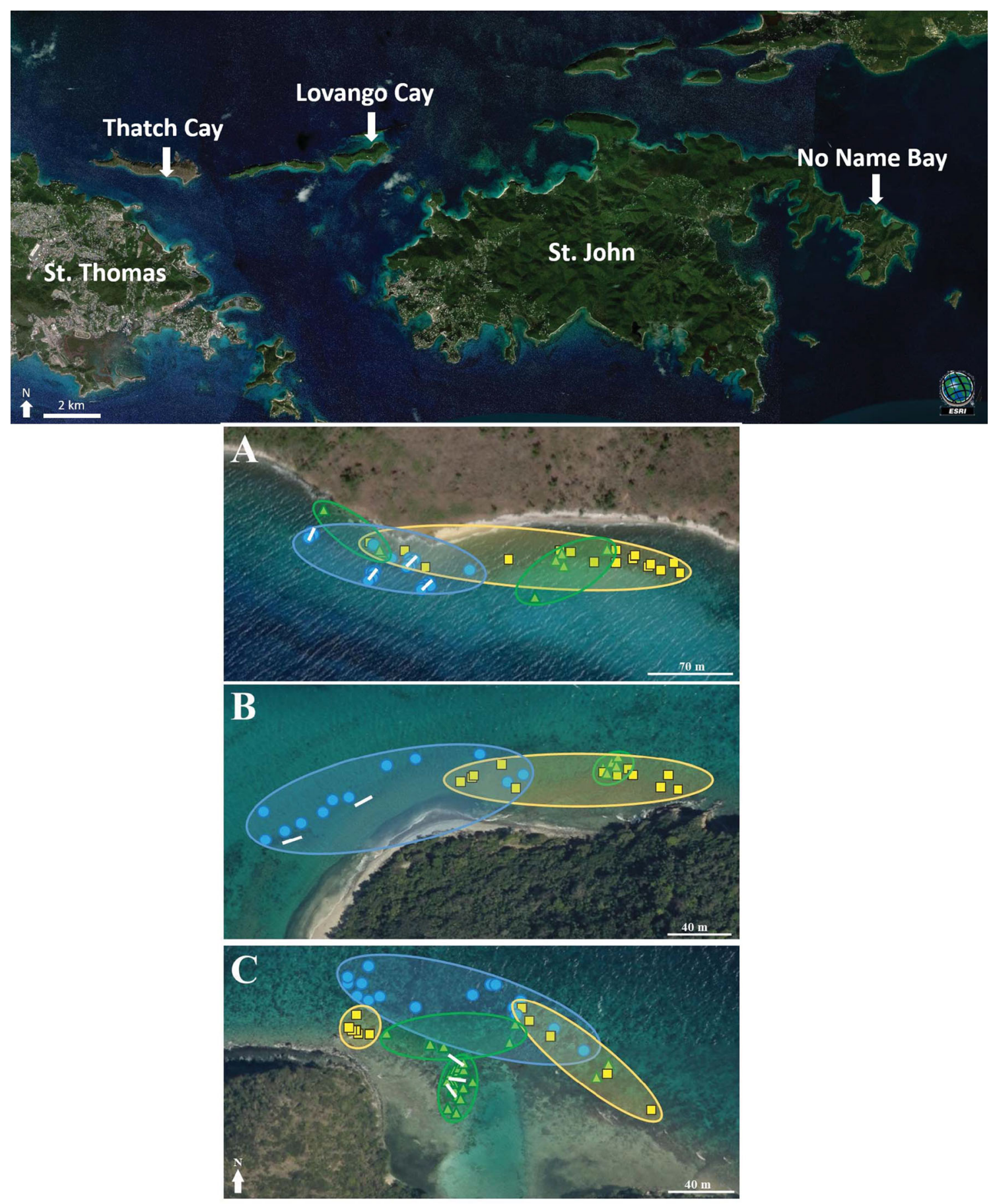

A. cervicornis A. prolifera

A. palmata

Fig. 2 Study sites in the U.S. Virgin Islands at A Thatch Cay (T1-4), B Lovango Cay (T5-6), and C No Name Bay (T7-9). Shaded areas represent locations where A. cervicornis (blue), A. palmata (yellow), and the hybrid $A$. prolifera (green), were most prevalent during genotypic sampling in 2017. White lines delineate permanent transects. Note, by 2017 A. cervicornis was no longer present on the transects at No Name Bay 


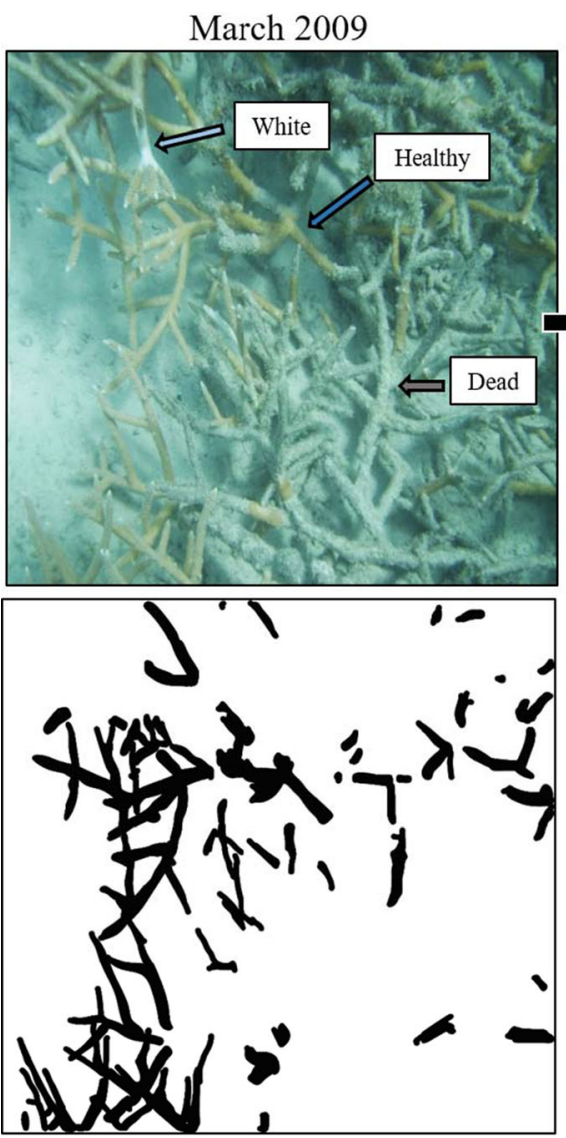

$15.8 \%$ coral cover
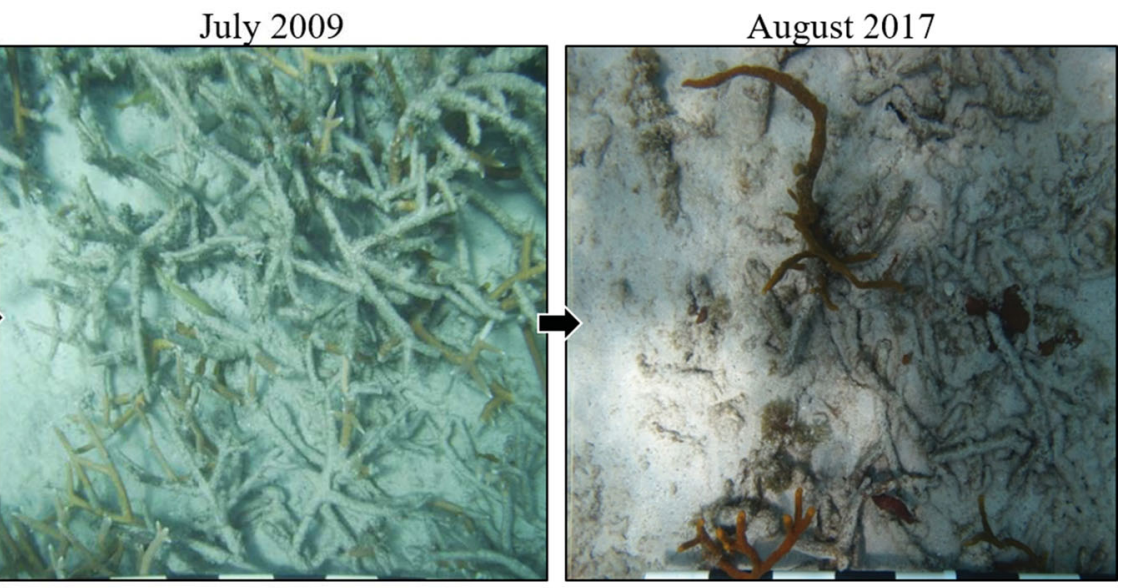

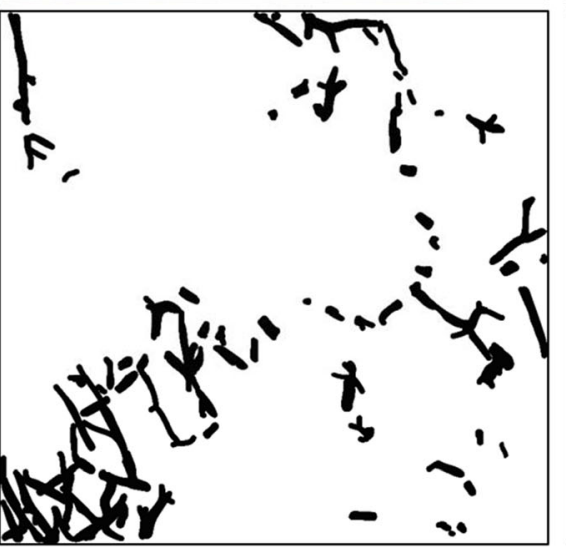

$8.4 \%$ coral cover

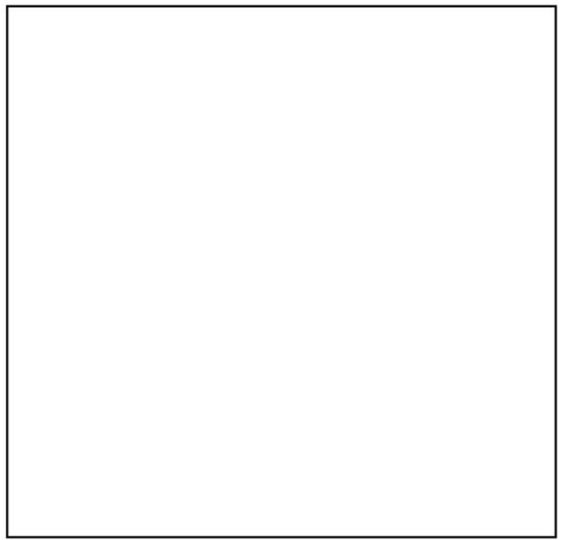

$0 \%$ coral cover
Fig. 3 Example of digitizing results using photos from Thatch Cay, Transect 3 in March, July, and August 2009. Pigmented, white, and dead colonies are highlighted in March 2009. Dead areas were not included in the average coral cover analysis, which quantified pigmented and white coral tissue. Note in August 2017, what appears to be pigmented branches is a rope sponge
Table 1 Genotypic richness among sites. $N$ is the number of sampled colonies, $N_{g}$ is the number of unique genets, and $N_{g} / N$ represents the genotypic richness

\begin{tabular}{|c|c|c|c|c|c|c|c|c|c|c|}
\hline & \multicolumn{3}{|c|}{ Thatch Cay } & \multicolumn{3}{|c|}{ Lovango Cay } & \multicolumn{3}{|c|}{ No Name Bay } & \multirow{2}{*}{$\begin{array}{l}\text { Total } \\
N_{g} / N\end{array}$} \\
\hline & $N$ & $N_{g}$ & $N_{g} / N$ & $N$ & $N_{g}$ & $N_{g} / N$ & $N$ & $N_{g}$ & $N_{g} / N$ & \\
\hline A. cervicornis & 22 & 15 & 0.68 & 12 & 5 & 0.42 & 16 & 11 & 0.69 & 0.62 \\
\hline A. palmata & 17 & 9 & 0.53 & 12 & 10 & 0.83 & 11 & 8 & 0.73 & 0.67 \\
\hline A. prolifera & 8 & 6 & 0.75 & 6 & 4 & 0.66 & 25 & 25 & 0.6 & 0.64 \\
\hline
\end{tabular}

where transects were nested within each site. A linear regression compared A. cervicornis and A. prolifera populations at No Name Bay.

\section{Results and discussion}

The number of genotypes varied among taxa and sites (Table 1). However, genotypic richness was high and was not significantly different among A. cervicornis, A. pal$m a t a$, and hybrids across the three sites ( $t$ test, F (2, $6)=0.32 p=0.74)$. Genotypic richness values at or above 0.6 (Baums et al. 2006) suggest that these populations originated primarily through multiple sexually derived hybridization events with occasional asexual propagation. These findings do not support the alternative hypothesis that hybrids predominantly propagate asexually following a rare hybridization event (Vollmer and Palumbi 2002). Even densely packed hybrid colonies contained multiple unique genets. For instance, one large hybrid thicket at No Name Bay contained 11 of the 25 unique genotypes identified at this site.

While molecular analysis provides a snapshot of reproductive patterns and persistence of genotypes, long-term transect data were used to document population changes over time. In 2009, transects were photographed three 
times, revealing intra-annual losses of A. cervicornis, particularly at Thatch Cay. Across sites, mean pigmented $A$. cervicornis cover declined significantly from $25.7 \% \pm 2.6 \%$ (SE) in March 2009 to $9.1 \% \pm 1.8 \%$ in November 2009 (ANOVA, DF $=2,9, F$-stat $=7.71, p$ value $=0.01)$. The significant declines observed in $A$. cervicornis in 2009 coincided with high summer temperatures that exceeded the predicted bleaching threshold (ESM Fig. 2.). Increased white areas on A. cervicornis are likely indicative of bleaching and/or disease associated with high temperatures (Muller et al. 2008). From 2009 to 2017, A. cervicornis cover declined significantly at all three sites (multiple linear regression, $\mathrm{SE}=2.47, t$-value $=$ $-6.42, p$-value $=<0.01)$. At Lovango Cay and No Name Bay specifically, A. cervicornis experienced significant declines and was lost from these sites by 2015 and 2017, respectively (Fig. 4; $F$-statistic $=-22.7, \mathrm{DF}=2,39, p$ value $=<0.01)$.

No Name Bay transects hosted both A. cervicornis and hybrid populations, providing a unique opportunity to compare their population dynamics. Throughout the study, mean pigmented hybrid percent cover remained significantly higher than A. cervicornis coral cover (linear regression, $\mathrm{SE}=1.35, t$-value $=-2.13, p$-value $=0.01$ ) Several stressors documented in this region including thermal stress, disease, and storm events (Miller et al.
2009; Rogers and Muller 2012) likely contributed to the inability of A. cervicornis to persist in these shallow reefs. Several major hurricanes including three in 2009, two in 2010, three in 2011, and three in 2014 directly impacted the U.S. Virgin Islands. These storms can exacerbate the decline and disappearance of acroporids and other corals through scouring, smothering, colony breakage, increased rates of disease, and tissue loss (Scoffin 1993; Rogers 1993). These impacts, singly or in combination, may have stressed some A. cervicornis colonies beyond their natural ability to recover. The decline of A. cervicornis in this study follows the trend of widespread losses seen throughout the tropical western Atlantic since the 1980s (Bythell et al. 1993; Hughes 1994; Aronson and Precht 2001). Limited occurrences of bleaching and/or disease in the hybrid are consistent with other research that found fewer afflictions (i.e., disease, predation, bleaching, parasitism) compared to the parental species across the Caribbean (Fogarty 2012).

Hybridization can facilitate the introduction of new genetic combinations that lead to novel adaptive traits, expansion of primary habitat ranges, or potentially restore populations via evolutionary rescue (Becker et al. 2013; van Oppen et al. 2015; Chan et al. 2019). In other biological systems, successful hybrids can act as invasive species through the removal, displacement, and reduction
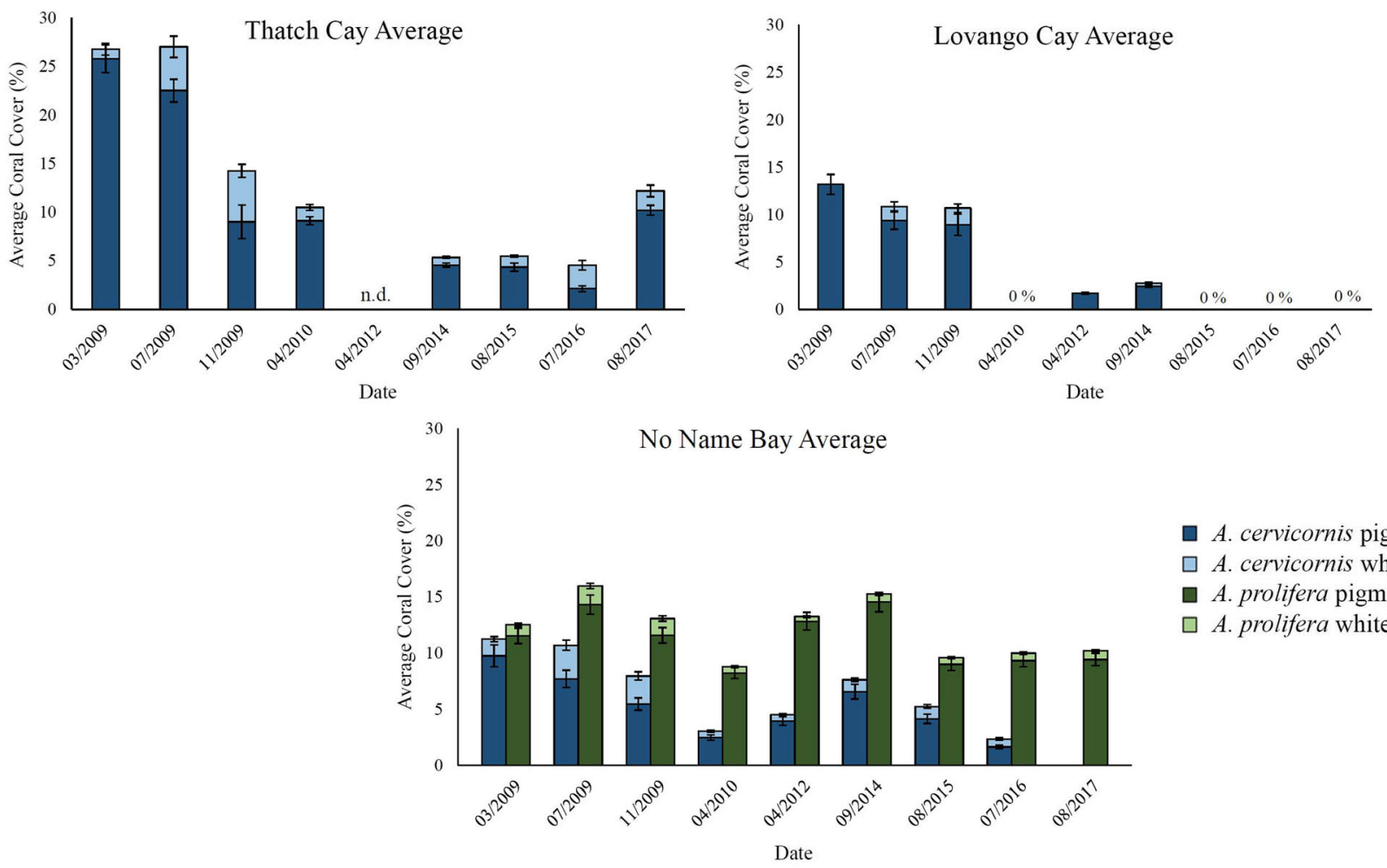

a. cervicornis pigmented $\square$ A. cervicornis white A. prolifera pigmented $\square$ A. prolifera white

Fig. 4 Mean percent cover ( \pm SE) of Acropora cervicornis (blue) and A. prolifera (green) along permanent transects in the USVI. Dark colors represent pigmented tissue and light colors represent white tissue or skeleton. Note, only 3 of the 4 transects were surveyed in 2014 
of native taxa (Lee 2002). For Caribbean acroporids, the impacts of introgressive hybridization are paradoxical, such that the parental species could benefit from gene shuffling (i.e., genetic rescue through shared alleles) or could become homogenized (i.e., genetic swamping) (Rieseberg et al. 1993; Ellstrand and Schierenbeck 2000; Rieseberg and Burke 2001). Because the hybrid does not provide identical morphological habitat to that of the parental species, the hybrid zone could support different assemblages of fish and invertebrate species, promote further hybridization in the organisms that occupy the newly formed habitat (Schwarz et al. 2005), create unique niches without speciation (Vollmer and Palumbi 2002), and potentially restructure shallow coral reefs (Weil et al. 2020).

The ecological implications of hybridization in Caribbean acroporids are crucial to consider, as the hybrid vigor observed in A. prolifera may be valuable to conservation and restoration initiatives. The high genotypic richness supports the hypothesis that multiple sexual reproduction events produced a diverse hybrid population in these shallow reefs. The persistence of the hybrid in environmental conditions that caused A. cervicornis declines suggests they face weaker selective pressure than the parental species and will likely continue to expand. It remains unknown whether the unique morphology of the Caribbean hybrid may introduce additional ecological changes compared to the parental species. What is clear is that Caribbean acroporid hybrids can tolerate and persist in very warm, shallow waters (this study; Fogarty 2012), potentially making them more resistant to changing ocean conditions.

Acknowledgements This research was funded in part by the AMLC Student-Grants-in-Aid, the NSF to N.D. Fogarty (OCE-1538469/ OCE-1929979), and the NOAA CRCP (Hill/Doerr). Permits were issued by the Government of the U.S. Virgin Islands, DFW (CZM17011U). Thank you to A. Vollmer, K. Enneking, C. VanWynen, and L. McManus for your invaluable assistance. Mention of any products or trade names does not represent an endorsement by NOAA or the authors.

Open Access This article is licensed under a Creative Commons Attribution 4.0 International License, which permits use, sharing, adaptation, distribution and reproduction in any medium or format, as long as you give appropriate credit to the original author(s) and the source, provide a link to the Creative Commons licence, and indicate if changes were made. The images or other third party material in this article are included in the article's Creative Commons licence, unless indicated otherwise in a credit line to the material. If material is not included in the article's Creative Commons licence and your intended use is not permitted by statutory regulation or exceeds the permitted use, you will need to obtain permission directly from the copyright holder. To view a copy of this licence, visit http://creativecommons. org/licenses/by/4.0/.

\section{References}

Aguilar-Perera A, Hernandez-Landa RC (2018) Occurrence of large thickets of Acropora prolifera (Scleractinia: Acroporidae) in the southern Gulf of Mexico. Mar Biodivers 48(4):2203-5

Aronson RB, Precht WF (2001) White-band disease and the changing face of Caribbean coral reefs. In: The ecology and etiology of newly emerging marine diseases. Springer, Dordrecht, pp 25-38

Baums IB, Devlin-Durante MK, Brown L, Pinzón JH (2009) Nine novel, polymorphic microsatellite markers for the study of threatened Caribbean acroporid corals. Mol Ecol Resour 9(4):1155-8

Baums IB, Miller MW, Hellberg ME (2006) Geographic variation in clonal structure in a reef-building Caribbean coral, Acropora palmata. Ecol Monogr 76(4):503-19

Becker M, Gruenheit N, Steel M, Voelchel C, Deusch O, Heenan PB, McLenachan PA, Kardailsky O, Leigh JW, Lockhart PJ (2013) Hybridization may facilitate in situ survival of endemic species through periods of climate change. Nat Clim Chang 3(12):10391043

Brock JC, Wright CW, Clayton TD, Nayegandhi A (2004) LIDAR optical rugosity of coral reefs in Biscayne National Park, Florida. Coral Reefs 23(1):48-59

Bythell J, Gladfelter EH, Bythell M (1993) Chronic and catastrophic natural mortality of three common Caribbean reef corals. Coral Reefs 12:143-152

Cairns S (1982) Stony corals (Cnidaria: Hydrozoa, Scleractinia) of Carrie Bow Cay, Belize. Smithson Contrib Mar Sci pp 271-302

Chan WY, Hoffmann AA, van Oppen MJ (2019) Hybridization as a conservation management tool. Conserv Lett 12(5)e.12652

Cortes J (2003) Latin American coral reefs. Elsevier Science, Amsterdam

Ellstrand NC, Schierenbeck KA (2000) Hybridization as a stimulus for the evolution of invasiveness in plants? Proc Natl Acad Sci USA 97(13):7043-50

Fogarty ND (2010) Reproductive isolation and hybridization dynamics in threatened Caribbean acroporid corals. Ph.D. thesis, Florida State University, pp 7-78

Fogarty ND (2012) Caribbean acroporid coral hybrids are viable across life history stages. Mar Ecol Prog Ser 446:145-59

Fogarty ND, Vollmer SV, Levitan DR (2012) Weak prezygotic isolating mechanisms in threatened Caribbean Acropora corals. PLoS One 7(2):e30486

Gignoux-Wolfsohn SA, Marks CJ, Vollmer SV (2012) White Band Disease transmission in the threatened coral, Acropora cervicornis. Sci Rep 2:804

Gladfelter EH, Monahan RK, Gladfelter WB (1978) Growth rates of five reef-building corals in the northeastern Caribbean. Bull Mar Sci 28(4):728-34

Gladfelter WB (1982) White-band disease in Acropora palmata: implications for the structure and growth of shallow reefs. Bull Mar Sci 32(2):639-43

Goreau TF (1959) The ecology of Jamaican coral reefs I. Species composition and zonation. Ecology 40:67-90

Hoegh-Guldberg O, Bruno JF (2010) The impact of climate change on the world's marine ecosystems. Science 328(5985):1523-8

Hoegh-Guldberg O, Mumby PJ, Hooten AJ, Steneck RS, Greenfield P, Gomez E, Harvell CD, Sale PF, Edwards AJ, Caldeira K, Knowlton N (2007) Coral reefs under rapid climate change and ocean acidification. Science 318(5857): 1737-42

Hughes TP (1994) Catastrophes, phase shifts and large-scale degradation of a Caribbean coral reef. Science 265:1541-1551

Japaud A, Fauvelot C, Bouchon C (2014) Unexpected high densities of the hybrid coral Acropora prolifera (Lamarck 1816) in Guadeloupe Island, Lesser Antilles. Coral Reefs 33(3):593 
Lee CE (2002) Evolutionary genetics of invasive species. Trends Ecol Evol 17(8):386-91

Miller J, Muller E, Rogers C, Waara R, Atkinson A, Whelan KR, Patterson M, Witcher B (2009) Coral disease following massive bleaching in 2005 causes $60 \%$ decline in coral cover on reefs in the US Virgin Islands. Coral Reefs 28(4):925

Muller EM, Rogers CS, Spitzack AS, Van Woesik R (2008) Bleaching increases likelihood of disease on Acropora palmata (Lamarck) in Hawksnest Bay, St John, US Virgin Islands. Coral Reefs 27(1):191-5

Randall CJ, van Woesik R (2015) Contemporary white-band disease in Caribbean corals driven by climate change. Nat Clim Chang 5(4):375

Rieseberg LH, Ellstrand NC, Arnold M (1993) What can molecular and morphological markers tell us about plant hybridization? CRC Crit Rev Plant Sci 12(3):213-41

Rieseberg LH, Burke JM (2001) The biological reality of species: gene flow, selection, and collective evolution. Taxon 50(1):4767

Rogers CS (1993) Hurricanes and coral reefs: the intermediate disturbance hypothesis revisited. Coral Reefs 12(3-4):127-37

Rogers CS, Muller EM (2012) Bleaching, disease and recovery of the threatened scleractinian coral Acropora palmata in St. John, US Virgin Islands: 2003-2010. Coral Reefs 31(3): 807-19

Schwarz D, Matta BM, Shakir-Botteri NL, McPheron BA (2005) Host shift to an invasive plant triggers rapid animal hybrid speciation. Nature 436(7050):546
Scoffin TP (1993) The geological effects of hurricanes on coral reefs and the interpretation of storm deposits. Coral Reefs 12(34):203-21

Stoddart JA, Taylor JF (1988) Genotypic diversity: estimation and prediction in samples. Genetics 118(4):705-11

Van Oppen MJ, Oliver JK, Putman HM, Gates RD (2015) Building coral reef resilience through assisted evolution. PNAS 112(8):2307-2313

Vollmer SV, Palumbi SR (2002) Hybridization and the evolution of reef coral diversity. Science 296(5575):2023-5

Wallace C (1999) Staghorn corals of the world: a revision of the coral genus Acropora (Scleractinia; Astrocoeniina; Acroporidae) worldwide, with emphasis on morphology, phylogeny and biogeography. CSIRO publishing

Weil E, Hammerman N, Becicka R, Cruz-Motta J (2020) Growth dynamics in Acropora cervicornis and A. prolifera in southwest Puerto Rico. PeerJ 8:e8435

Yang J, Yu K, Gong Y, Huang T (2009) Linear spatial pyramid matching using sparse coding for image classification. In: 2009 IEEE Conference on computer vision and pattern recognition, pp 1794-1801

Publisher's Note Springer Nature remains neutral with regard to jurisdictional claims in published maps and institutional affiliations. 